\title{
PUBLIC FINANCE MANAGEMENT IN GEORGIA
}

\author{
M. Chelidze1, G. Gelitashvili ${ }^{2}$ \\ DOI: http://doi.org/10.15350/L_26/9/2
}

\begin{abstract}
After Georgia experienced transition to market relations, the financial management system has radically changed. In addition to the Ministry of Finance, other important organizational structures for management of finance are State Audit Office, independent audit financial control offices and so forth.

Within the public finance management reform, the activities planned in the direction of budgeting ensure effective management and transparency of public finance, mobilization of the resources required for implementation of the planned policy with the purpose to develop various sectors, at the same time maintaining fiscal stability; and in parallel with fulfilment of social obligations, implementation of the fiscal policy supporting economic growth.
\end{abstract}

Keywords: Public finance management; Public finance management reform; Effective management and transparency of public finance; Fiscal stability; Maintenance of fiscal discipline.

Centralized budgeting system was replaced by the new budgeting system, which was based on the underlying principle of real independence of different level budgets and their equality. Here, we mean generation of revenues on its own and/or through regulatory duties and freedom of expenditure (within the law). In addition, new relationships and obligations were formed - state budget makes transfers to the budgets of autonomous republics and local budgets.

In Georgia, Management of Finance is carried out by the Ministry of Finance of Georgia based on the Constitution of Georgia and the respective laws adopted by the Parliament. Specifically, the Ministry of Finance uses the Constitution of Georgia, international agreements and arrangements, the Law of Georgia on the Structure, Authority and Rules of Operation of the Government of Georgia", Budgetary Code of Georgia, Tax Code of Georgia, other legislative acts, normative acts of the President of Georgia, legal acts of the Government of Georgia and Prime-Minister of Georgia, statute of the Ministry and other legal acts as a guide for its operations.

Ministry of Finance of Georgia is a central executive government agency, which is engaged in public administration of finance, budgeting and taxation, ensures development and compliance with the budgeting, tax and accounting legislation at the territory of Georgia, carries out preventive operative-investigatory

1Medea Chelidze, Candidate of Economic Sciences, Associate Professor, Georgian Technical University, Georgia.

${ }^{2}$ Goga Gelitashvili, Student, Georgian Technical University, Georgia. 
activities, research and preliminary scrutiny in the field of economic offence.

The purpose, objectives, functions, responsibilities and powers of the Ministry of Finance of Georgia are outlined in the statute of the Ministry ${ }^{1}$, which is approved by the Prime Minister of Georgia. The Ministry is accountable to the government and carries out tasks envisaged in the legislation or assigned by the Government and Prime Minister of Georgia on the ground of the legislation.

The Ministries of the autonomous republics included in the system of Ministry of Finance of Georgia are: Ministry of Finance of Autonomous Republic of Abkhazia and Ministry of Finance and Economy of Autonomous Republic of Adjara.

State sub-departments within the governance of the Ministry of Finance of Georgia are State Treasury and Investigation Service of Ministry of Finance.

Legal entities under Public law within the governance of the Ministry of Finance of Georgia are: Revenue Service; Financial Analytical Service; Service Agency of Ministry of Finance; Academy of the Ministry of Finance.

The Ministry is accountable to the government and carries out tasks envisaged in the legislation or assigned by the Government and Prime Minister of Georgia on the ground of the legislation.

The Ministry develops main directions of fiscal policy and drafts of the respective legislative acts, reviews proposals based on the constitution of Georgia and the law on budgeting system with respect to balancing of the budgets elaborated by the governing authorities of the autonomous republics of Abkhazia and Adjara and other territorial units of Georgia. In addition, the Ministry develops draft of state budget of Georgia, economic norms for formation of the budgets of autonomous republics of Abkhazia and Adjara and other territorial units, and draft volumes of transfers to be made to or received from such budgets, manages state budget to ensure that the budgetary revenues are stable and that the state financial resources are used rationally. Together with the respective local authorities, it performs activities to ensure that the budgets of all levels of the country are fulfilled.

The Ministry is led by the Minister who is appointed by the Prime Minister of Georgia. The Minister of Finance represents the Ministry, governs is activities and makes decisions with respect to the issues within the scope of Ministry's activity; is responsible for performance of the constitution of Georgia, international agreements and arrangements, legislative acts, normative acts of the President of Georgia, resolutions and ordinances of the Government of Georgia, orders of the Prime Minister of Georgia within the scope of the Ministry's governance.

The level of financial management experiences systemic maintenance. It largely depends on the organizational structure of the independent finance office, qualifications, responsibility and discipline of the employees, forms and methods used in the process of financial management.

According to the document by the Government of Georgia ("Public Finance Management Strategy", 2014-2017), the reforms to be carried out in the field of

1 This statute is approved by the resolution \#341 "About approval of statute of the Ministry of Finance of Georgia" dated 17 December 2013 by the Government of Georgia. 
public finance management include the following five priority directions: 1 . Maintenance of fiscal discipline and improvement of fiscal forecasting. 2. Improvement of planning of state finances; 3 . Management, accounting and reporting of the state finances; 4. Internal state control; 5. Development of the state electronic services in public finance management and coordination of donors.

According to the document by the Government of Georgia ("Basic data and directions for 2015-2018"): the government ensures public finance management because, on the one hand, the budget must support increase of expenditures on priority fields and social issues, and on the other hand, the budget must stimulate the economy and at the same time maintain fiscal stability of the country.

The unified standards for planning will be developed which will be related to the national, as well as field-related and other sectoral medium-term strategic documents. Medium-term plans will be used as an effective instrument to achieve fiscal stability. With the purpose to stimulate the economy, in addition to increase of the budgetary expenditure, it is also possible to increase budget deficit in the specific period, however it will be maintained at the low level in the medium-term. In the medium and long-term it is important to maintain basic macroeconomic and fiscal indicators which may improve the assessments of ranking companies and make the country attractive from the perspective of the investment climate.

The direction of macroeconomic analysis and forecasting of the Ministry of Finance will be improved. With the purpose to improve the budget planning process, the process of medium-term forecasting of tax revenues of state and consolidated budget will be improved; the forecasting will be broadened in order to cover economic sectors broadly; time frame of forecasting will increase which will increase the opportunity of long-term planning in fiscal sector.

During formation of the state debt, stability of the debt portfolio will be ensured. The loans will be attracted with the best terms, based on the necessity. The need to develop local securities market and support economic activity will be taken into consideration within this process.

Further work will be carried out in the direction of introduction of program budget and improvement of the respective methodology, including, development of the methodological guidance for spending entities which will assist them in effective management of the internal process of program budget preparation.

Budgeting oriented on results will be fully implemented. Mechanisms of representation of the programs and sub-programs implemented by the budget, as well as their expected outcomes will approach the internationally acceptable standards. Further work will be carried out to increase transparency and informative nature of the budget and all interesting and required information will provided to the Georgian citizens in a simple form.

Further work will be carried out to broaden the functional abilities of the electronic budgeting system (e-Budget). The process of elaboration of the budgets of legal entities under public law, autonomous republics and local self-governing units will be included into this system.

The accounts of the legal entities under public law, autonomous republics and local self-governing units will be opened in the unified state treasury system and 
they will be managed through the unified information system of state treasury finance management, which will achieve full and timely reporting of budgets of all levels and operations carried out with the financial resources of legal entities under public law and will improve the quality of accountability.

International accounting standards for public sector will be implemented stage by stage, and once the full compliance is achieved with these standards, financial statements of the government will be published annually, based on accruals method.

At last, the mechanisms for internal, as well as external control and audit will improve in the field of public finance management. With the purpose to improve the budgeting process, effective mechanism for the use of conclusions and recommendations will be provided by the state audit office.

References:

[1] Mosiashvili V., Chelidze M. - Finance, Texbook - Tbilisi, «Dani». 2016.

[2] http://gov.ge/files/423_49307_626772_PAR_Geo_Draft(1).pdf

[3] http://mof.ge/4832

[4] http://mof.ge/4804

[5] http://treasury.ge/4968 